\title{
"A Superabundance of Music": Reflections on Vienna, Italy and German Opera, 1912-1918
}

Robert Blackburn

Romain Rolland's remark that in Germany there was too much music $^{1}$ has a particular resonance for the period just before and just after the First World War. It was an age of several different and parallel cultural impulses, with the new forces of Expressionism running alongside continuing fascination with theicons and imagery of Jugendstil and neo-romanticism, the haunting conservative inwardness of Pfitzner's Palestrina cheek by jowl with rococo stylisation (Der Rosenkavalier and Ariadne auf Noxos) and the search for a reanimation of the commedia dell'arte (Ariadne again and Busoni's parodistic and often sinister Arlecchino, as well as Pierrot Lunaire and Debussy's Cello Sonata). The lure of new opera was paramount and there seemed to be no limit to the demand and market in Germany. Strauss's success with Salome after 1905 not only enable him to build a villa at Garmisch, but created a particular sound-world and atmosphere of sultriness, obsession and irrationalism which had a profound influence on the time. It was, as Strauss observed, "a symphony in the medium of drama, and is psychological like all music". ${ }^{2}$ So, too, was Elektra, though this was received more coolly at the time by many. The perceptive Paul Bekker (aged 27 in 1909) was among the few to recognise it at once for the masterpiece it is. ${ }^{3}$ In 1911 it was far from clear that Der Rosenkovalier would become Strauss' and Hofmannsthal's biggest commercial success, nor in 1916 that Ariadne auf Noxos would eventually be described as their most original collaboration. ${ }^{4}$ 
In the decade 1912-22, the rising stars of German opera were both Austrians: Franz Schreker, born in 1878, and the very young Erich Korngold, born in 1897. It is Christopher Hailey's new biographical study of Schreker which prompts this essay. ${ }^{5}$ I shall be looking here at a group of works belong to the dying years of the "Italian Renaissance" or "Renaissanceism" boom on the German stage, a fashion dating back to the 1870s.

The demand for new German-language operatic works inevitably meant an intense search for libretti. One solution was for the composer to write his own. Schreker did so, and came in for criticism virtually from the start for naivete and lack of finish, though Universal Edition proudly published his texts in two volumes in 1922 at the height of his fame. In the libretto for Palestrina, written in 1910-11, Hans Pfitzner produced one of thevery fewoperatic libretti which deserves to beread independently as a work of literary merit. It took him the next three and a half years to compose the music. The other extreme was the over-prolific Eugen d'Albert (1868-1932) who never wrote his own, and was always on the look-outfor fresh sources, rarely discriminating overquality. Tastelessness abounded here, and works like Der Stier von Olivera, Revolutionschochzeit and Scirocco vanished as quickly as they had appeared. Tiefland (1903) apart, d'Albert has not shared the fresh attention received by this period during the last twenty years, as new perspectives have arisen on largely forgotten or marginalised figures. Zemlinsky, Schreker and Korngold (all Vienna-trained) as well as Pfitzner, Busoni and even Max von Schillings have benefited from this slow process of revaluation, through performance and scholarship.

The point has been made that Vienna's very baroque solidity (the quality that endeared it to Richard Strauss) made it seem all the more "unreal" in the period of the final Habsburg decline. Though we can see the extraordinary intellectual and cultural energy of Vienna in the three decades leading up to 1914 , a strange paradox is also visible. Historians have commented on the way the mores of Vienna in the last years of the Austro-Hungarian monarchy seemed to relate to a "Traumbild" or dream-image which had little to do with the dynamic present elsewhere. ${ }^{6}$ Karl Kraus, who started his journal Die Fackel (The Torch) in 1899 observed in July 1914 that Austria-Hungary was "an experimental 
station for the end of the world", a prophecy only too well-founded. This was a cosmopolitan city perceived by its citizens to be dominated by Jewish cultural norms and achievements, though the Jews were in a small numerical minority. As Steven Beller has shown, this largely correct view exacerbated an endemic anti-semitism. ${ }^{7}$ Between 1908 and 1913, the young Hitler lived in Vienna and the circumstances of Jewish cultural hegemony, coupled with visible extremes of wealth and poverty, led him in the 1920s to paint a black propaganda picture in Mein Kampflargely based on his experiences in this one city. But for Richard Strauss, this same Vienna on the 1920s was congenial in spirit, through his continuing association with Hofmannsthal. After the Dresden premiere of Die Frau ohne Schatten (a profoundly Austrian work) in 1919, Strauss turned increasingly to Vienna as the centre of his activities, working until 1924 with Franz Schalk as co-director of the Staatsoper. It is well known that this experience ended sourly. But the issue here, not always sufficiently recognised, is the continuing Viennese association following Hofmannsthal's death in 1929, though Zweig, Gregor and Clemens Krauss.

\section{II}

We need to recall, first of all, that these pioneering works of Expressionist music theatre, Schoenberg's Erwartung (Expectation) and Die glïckliche Hand (The Knack), though emphatically part of the pre-war creative ferment in Vienna, were not actually performed until 1924, when Zemlinsky gave them in Prague and Vienna respectively. Historically these two experimental works belong to the period 1909-13, as also does Kandinsky's stage composition Der gelbe Klang. ${ }^{8}$ The abstraction of these works arose directly out of existential crises. They werenon-realistic to the last degree, certainly non-cinematic: Schoenberg exclaimed that he was aiming at "the utmost unreality". Secondly, the genesis of Wozzeck, most deservedly celebrated of modernist operas, goes back to 1913, when Berg saw a production of Büchner's Woyzeck in Vienna. Wozzeck's appearence in Berlin in 1925 revealed the full possibilities of highly-organised atonal musical expressionism in a 
recognisable realist narrative context, at a time when rapid cultural change was in the air, and the Expressionist movement as a whole was generally seen to have run its course. So in one sense these three key modernist works, all emerging from a specifically Viennese ambience, became part of alater, still more complex reception history, as performers (especially singers) gradually learned to master their technicalities, and the public learned even more slowly to enjoy them as music. My point is that they really belong to the history of post-1945 modernism, and thus need to be seen alongside Mose urn Aron and Lulu, two later unfinished masterpieces. The one represents the metaphysical-ethical-religious, the other the social-erotic-daemonic aspect of early to mid-20th-century hermeneutics. Each arises out of a thoroughgoing, obsessional working out of individual serial techniques. Crucially, the reception history of these two great works really belongs to the time of European reconstruction and renewal.

Two important non-Viennese works of the First world War period share a sixteenth century background, a certain historical-mythic quality and an aspiration towards monumentality. Pfitzner completed his score of Palestrina: amusical legend on 24 June 1915. On 26 December 1914 Busoni finished his text for Doktor Faust: Dichtung fur Musik, a work he was not destined to complete. It was finished by Philipp Jarnach after Busoni's death and first performed in Dresden in 1925. At one time, it would have been thought odd to place them together, so far apart were Pfitzner and Busoni in personality, musical style and attitudes to the past, present and future music. How could the author of the abrasive conservative polemic Futuristengefahr (TheDanger of the "Futurists") have anything in common with the pioneer of the new classicism, visionary of new modes of music-making, and author of Towards a New Aesthetic of Music, with its far-reaching sense of what music might become?" John Williamson has described Palestrina as "a parable of inspiration" 10 yet Busoni's opera could also be said to deserve this comment. They are both confessional works. Bruno Walter, first conductor of Palestrina, said that "intensity" was the word needed to describe Pfitzner; Edward Dent also saw that despite the beauty of the text, the composer had played fast and loose with historical accuracy, despite his thorough use of sources. ${ }^{11}$ Part of the Preface from 
Schopenhauer which Pfitzner placed at the head of his score runs: "The life of the mind hovers, like an intangible aura and fragrance, above worldly cares, as the true reality." Curiously, Busoni might have agreed with that, though it is hard to imagine the composer of Arlecchino: a theatrical capriccio (1914-16) choosing such a motto, even though his conception of the one-act burlesque changed towards the sombre after the beginning of the war. Pfitzner's Schopenhauer extract (from the end of The World as Will and Idea) declares that the history of philosophy, science and the arts ("die Geschichte der Philosophie, der Wissenschaft, und der Künste) parallels world history, guiltless and unstained by blood". In thefinal scene of Doktor Faust, Busoni, having lived this work as profoundly as Pfitzner lived Palestrina, chose a spoken epilogue, closing with the words.

\author{
Let each take what he finds appropriate \\ The seed is sown, others may reap the field. \\ So, rising on the shoulders of the past \\ Mankind will close the circle at the last. ${ }^{12}$
}

Astonishingly, Beaumont reveals that only several years after the work's première was Jarnach given a single sheet of MS paper containing Busoni's own completion plan for Doktor Faust, which obviously differs considerably from his own attempt. Beaumont's own completion, based on Busoni's plan was given in the striking English National Opera production in 1986, the first-ever staged performance in Britain.

Palestrina and Doktor Faust are two works which share more in retrospect than they seemed to before 1939, partly because Busoni posthumously became a target of Nazi denunciation after 1933, while Pfitzner the nationalist openly supported the new regime. Technically, the two works are constructed around the relationship of two men, each a baritone (Palestrina, Faust) and a tenor (Cardinal Borromeo, Mephistopheles) with a large men's chorus (Act 2 of Palestrina) and a students' chorus/ensemble in Doktor Faust. But we have no difficulty in seeing them as embodiments of the tragic destiny of the artist, his mystic relationship with a higher realm, and the problem of this in relation to the "real" world - central themes in German literature just after 1900. It is 
not surprising to find Thomas Mann, who had written about this in Tristan, Tonio Kröger and Tod in Venedig, responding so warmly to Palestrina when he saw the Munich premiere in 1917. Never one to wasteanything, Mann saw thelinks between Palestrina's spiritual-artistic world and the turbulent reality of Act 2 and the Council of Trent, which he felt combined satirical humour and deep pessimism about the possibility of effective political action. ${ }^{13}$ There was also the "sympathy with death" notion mentioned by Pfitzner to Mann, which to the writer's amazement mirrored exactly the preoccupation behind Der Zauberberg, which he was writing at that time. ${ }^{14}$ Another commentator felt that Act 2 was a kind of symphonic Scherzo, suggesting that Pfitzner wanted to portray the materialistic, outward world of the priest by profession, as distinct from the artist's inward, idealistic world. ${ }^{15}$ Bekker, stressing that the work "drew its strength from a speculativeidea" madea parallel with Die Meistersinger, observing that "Rome is Nuremberg, Palestrina is Sachs, theCouncil of Trent is the festivemeadow and competition scene, while the visions of the Old Masters (Josquin etc.) are the Song School". But Mann, following Pfitzner himself disagree with this, pointing to Palestrina's quiet, withdrawn end. ${ }^{16}$

\section{III - Literary Renaissanceism}

In after 1867 Die Meistersinger seemed an inescapable influence on any later German opera set in the sixteenth century, it had little to do with the fashion which developed strongly in the German theatre for subjects drawn from the High Italian Renaissance. One distinguished German literary historian commented that "the unstable world of the Roman emperors, the powerplay (Cäsarentum) of the Renaissance were givennew life and placed in the present... Peoplefound inblissful southern islands mid-ocean settings for glorious adventures, passions and crimes. It is very province of Romanticism". ${ }^{17} \mathrm{He}$ was referring to a tradition which had begun with J. J. Heinse's minor but still remarkable Sturm und Drang novel Ardinghello and the Fortunate Islands of 1787, in which all the elements of aesthetic immoralism to be developed a century later 
were present. Beauty, ruthlessness, action, revenge, passion and scandal are the main ingredients. They were developed by Stendhal in his Chroniques Italiennes and History of Painting in Italy (1817), by Byron in his two historical tragedies on Venetian themes (Marino Faliero and The Two Foscari, 1820-1) and by Victor Hugo some years later in Lucretia Borgia (1833) and Angelo, Tyrant of Padua (1835). Here espionage combines with murder and incest in an ecstasy of theatrical and rhetorical exaggeration.

What began in Germany in the 1870s with the work of very minor figures like Arthur Fitger and Albert Lindner became a torrent by 1900 , involving writers such as Bleibtreu, Wildenbruch, Heyse, Ludwig, Gottschall and Wilhelm Weigand, whose cycle Die Renaissance (1899 to 1909) is typical of the time. Even the young Rilke contributed Die weisse Furstin: eine Szene am Meer in $1899 .{ }^{18}$ Few, if any of these plays had real literary quality or lasting value, but they were given all over Germany. The favourite subjects by far were Cesare Borgia and Savonarola (brute animal power and sinister fanaticism respectively) followed by Marino Faliero(again), Raphael, Michelangelo and Aretino, together with the story of Francesca da Rimini from thirteenth century Ravenna. Wilde's Duchess of Padua (1882) and A Florentine Tragedy fragment (1894) were a part of this: so were d'Annunzio's Traum eines Friihlingsmorgens (Spring Morning Dream, 1900) and Maeterlinck's Monna Vanna, an Italian Renaissance drama set in Pisa, which swept across Germany in Oppeln-Bronikowski's translation in 1902-3. ${ }^{19}$ Wedekind, Beer-Hoffmann and Schnitzler wereall drawnin, thelast with his Der Schleier der Beatrice (Beatrice's Veil) of 1900/1, wich featured Lionardo Bentivoglio, the Bolognese duke who is "ein Magnifico ... Kondottiere und Kunstler zugleich ... ein Konig des Lebens" (a magnifico, at once condottieri and artist ... a prince of destiny). ${ }^{20}$

Several refined short works on Renaissance subjects, heavily Nietzsche-influenced, came from the precocious Hafmannsthal during the 1890s. The first of these, Gestern (1891) reflected its time in the use of the phrase "die Zeit der grossen Maler" (the age of the great painters). ${ }^{21}$ In Der Tod des Tizion (Titian's Death, 1892) astoundingly written when Hofmannsthal was only eighteen, the preoccupationis with the conscious being of a great painter on his deathbed, with a vision of 
the Venetian Renaissance filled with achievement, but alas with the continued problem of the division between hermetic art and the grossness of the world. Hofmannsthal had perhaps been saturated in the theme at too early an age; he went on to develop his passion for Venice of a later period, that of Casanova, in Der Abenteurer und die Sängerin (The Libertine and the Prima Donna, 1898) and Cristinas Heimreise (1909) with the fine reworking of Otway's Venice Preserved (Der Gerettete Venedig, 1905) in between. Here Venice is presented as a city of unique beauty, voluptuousness and amorous suggestiveness, as in the MullerKorngold Violanta. Inthe rococo fragment Andreas oder Die Vereinigten (1912-13, published 1930) Herr von Ferschengelder encounters a noble Carinthian girl, Romana Finazzer, on his way to Venice. There the topography becomes for Andreas a metaphor for the fast developing complexities of his own personality and thought, what Hermann Broch called "athicket of psychicidentificationsand antagonisms... amasquerade of themind". ${ }^{22}$ "Renaissanceism" gained extraimpetusthroughHeinrich Mann's novel Die Göttinnen of 1903 where the term "hysterical Renaissance" first appeared. The following year his brother Thomas implicitly criticised Renaissanceism in his play Fiorenza in the dialogue between the dying, crippled Lorenzo dei Medici and the ascetic moralist Savonarola. Nietzsche is an undeclared presence throughout; Mann comes douwn firmly on Savonarola's side, and against worldliness, luxury, sensuality and self-indulgence.

Burckhardt's Civilisation of the Renaissance in Italy (1860) had been deep, searching stimulus and focus of historical awareness of vital importance. But it is likely that "Renaissanceism" a literary-dramatic cult would have happened anyway, as apart of the expansionist climate of the late nineteenth century German Reich. The Italian Renaissance becamewide-ranging metaphor for power, colour, beauty, transcendence and individual magnetism. Nietzsche's familiar exaltation of Cesare Borgia as Pope (Antichrist, 1888), the principle of secular freedom and energy, had been preceded in Menschlich, allzumenschliches (Human, all too human, 1879) by the glorification of the Italian Renaissanceas "the golden age of thelast thousand years (involving) the liberation of thought, the disregard of authorities, the triumph of education over the darkness of tradition, enthusiasm for science, the unfettering of the individual". 
But it was Count Arthur Gobineau's LaRenaissance: scènes historiques of 1877, six dialogue-portraits presenting a twin image of the Italian Renaissance as a time of "Schönheit" and "Ruchlosigkeit", ecstatic beauty and self-determining morality based on strenght and unscrupulous hedonism, which most clearly mirrored German taste. Though, oddly, it was not translated until 1896 (Walter Pater's lectures The Renaissance were not translated until 1910) seven translationsin all appeared between then and 1928, with the Insel Verlag edition by Bernhard Jolles (1911) the most commercially successful. For Gobineau (regrettably also the author of Essai surl'inégalité desraces humaines) who had died in 1882, this was a remarkable record.

The late 1890s sawStrauss, Schillings and Pfitzner developing their musical careers in Germany, and the slightly younger Zemlinsky, Schoenberg and Schreker beginning theirs in Vienna. The time was described by Hermann Bahr in his reference to the Neuromantiker (neoromantics) in his 1894 essay Die Décadence. With acuity, he saw the threehallmarks ofneo-romanticism as a sharp move away from "vulgar" popular taste, a yearning for the "artistic" (Künstlichen) and a feverish search for the "mystic". "Thaey seek allegories", he wrote, "and sombre, dark images. Everything must have a second, hidden meaning, revealed only to the initiated. In the end, everything is for them as insatiablejourney towardsthe monstruous(Ungeheure) and the boundless (Schrankenlose). They assiduously seek the strange exception (seltsame Ausnahme)". ${ }^{23}$ The tone of mockery is clear, but so also is the sense of fascination. Many years later, Robert Musil satirised the time in a compelling passage early in Der Mann ohne Eigenschaften which has been seized on more than once.

One had faith and was sceptical: one was naturalistic and precious, robust and morbid, one dreamed of ancient castles and shady avenues, autumnal gardens, glassy ponds, jewels, hashish, diseaseand demonism, but also of prairies, vast horizons, forges and rolling mills, naked wrestlers, the uprising of the slaves of toil, man and woman in the primeval garden, and the destruction of society. ${ }^{24}$ 
Musil the engineer saw clearly and with searching irony that out of the haze of often perverse and self-indulgent. Jugendstil symbolism, the modern world in all its revolutionary imagery was inexorably forcing itself through.

\section{IV - Korngold and Zemlinsky}

It was not surprising that after such an immersion, Hofmannsthal rejected Strauss' request in 1906 for a full-blooded "Renaissance" subject as their first collaboration. In no other era, he declared, was life more "utterly alien" to the present. "Subjectstaken from the Renaissance seem to transport the brushes of the most deplorable painters, and the pens the most hapless of poets". ${ }^{25}$ Happily, he pushed Strauss in other directions. Many yearslater, Strauss conducted the only non-Viennese "Renaissanceist" opera of the period, Max von Schillings' Mona Lisa in Vienna in Hans Gregor's 1923 production; it was also given at the Metropolitan Opera House, New York, that same year. Schellings' operatic career had never really blossomed, but when early en 1913 he received a text from the Viennese playwright Beatrice Dovsky which amounted to a fictitious "penny-dreadful" on the theme of Leonardo's Mona Lisa, he set to work at once, and the work was given at Stuttgart on 26 September 1915. Its composition thus parallels that of Schreker's Die Gezeichneten, though Schreker's text was written in 1910. Dovsky was well enough thought of in Vienna for her play Der alte Herr to open the Vienna Burgtheater on 7 December 1905. However, her Mona Lisa text, directly influenced by Ernst von Dombrowsky's 1911 play, is structurally awkward, with its present-day prologue and epilogue; it is dramatically over-dependent on the physical effect of Francesco del Giocondo's two-section jewel cabinet in which first Fiordalisa's lover, Giovanni de'Salviati, then Francesco himself are imprisoned and suffocated. Julius Korngold actually thought quite well of the libretto, but pointed out that cupboards on stage rarely make for tragic effect.

Frau von Dovsky wanted to create a picture of Florence at the end of the 15th century and set the scene on carnival night in 1492, at the height of Savonarola's power in the city. The Vemuszug of Act 1 is 
indebted to Burckhardt's account of Renaissance festivals, while the Marienchor, with Savonarola and his San Marco monks help to create animage of Florence as an abandoned whore, inurgent need of salvation. At the outset, the Laienbruder (Lay Brother) prepares the audience for Fiordalisa Gherardini's enigmatic, withdrawn character:

Ein unergründlich Rätsel ist das Weib. In seiner Seele schlummern unbewusst an tausend Möglichkeiten.

(Woman is a fathomless mystery. A thousand possibilities slumber unknown within her soul).

Francesco's palace and pearls are symbols of worldly wealth, and are also pointers to inescapable doom. Wilhelm Raupp overpraised in in 1935 , in an attempt to boost Schillings' posthumous reputation during the Nazi period, but Karl Kraus was earlier appalled by the crassness of the text, whatever he may have thought of Schillings' pleasing but on the whole conservative score. Nevertheless, Mona Lisa achieved a very large number of performances between 1915 and the end of the 1920s; it remained unperformed between the 1940s and 1983.

After Maeterlinck, the most influential foreign authors in Germany from 1900 were Poe (died 1849) and Wilde. Hedwig Lachmann's translation of Salome, used by Strauss for his one-act opera, is obviously the best known of these, but she also wrote a study of Wilde (1905), one of six biographical-critical books on Wilde published in Germany between 1903 and 1908. So widespread was the Wild cult in Germany and Central Europe that it seems natural to see The Birthdory of the Infanta used by Schreker, then aged 30, as a basis for a ballet-pantomime in 1908. A year earlier, Max Meyerfeld had translated into German $A$ Florentine Tragedy at a time when A Picture of Dorian Groy was running through many editions in Germany. Just as important was Hauptmann's Silesiantragedy UndPippatanzt! - ein Glashïttenmarchen which was given many times in Vienna during the years to 1920. Venice plays a vital part in this realistic-fantastic story. The gentle, fairy-like dancer Pippa is the symbol of "the eternal longing of the German soul to move from darkness into brilliant light", as Hauptmann put it. For 
Michael Hellriegel, whose very name mean "bar to light", Pippa is only part of his vision of complete beauty. The total vision is to be found in a glass gondola shown to him by the magician Wann, which becomes a symbol of Venice's "frozen, timeless, marmoreal beauty". It is not surprising that Schreker was strongly influenced by this play in his second opera, the medieval "Mysterium" Das Spiehwerk un die Prinzessin (1911-12). Here, Florian, the Princess and the wandering youth have clear antecedents in Hauptmann's play. Berg considered it briefly before settling on Wedekind for his second opera. Venice in Hauptmann is a symbol of unearthly happiness, whereas in most Venetian dramas it represents frank sensual enjoyment, unbridled hedonism or fatal dionysiac power, as in Tod in Venedig. Schreker used the "Casanova" setting in Derferne Klang, by a coincidenceits "present day" dramaturgy parallels that of Mann's Tod in Venedig which appeared in 1912, the year of Der. ferne Klang's first performance.

Before Dovsky's Mona Lisa text and Schreker's text for Die Gegeichneten, very few staged operas on Italian Renaissancethemes had appeared; chief of them were, startlingly, Stanford's Savonarola (1884) and Leoncavallo's Die Medici (1894), both given in Germany. So when in 1913 Schreker claimed that a "Renaissance" theme would be a novelty in a German opera, he was actually quite correct. The way in which the Korngold family took up the text of Violanta was quite arbitrary. Hans Müller was a Viennese journalist and an experienced minor playwright, born in Brno, who had once contributed to Julius Korngold's Sonntagszeitung. ${ }^{26} \mathrm{He}$ offered the 17 year old Erich the choice between the historical Savonarola and a fictitious fifteenth century Venetian beauty, Violanta, wife of Captain Simone Trovai. Violanta is obsessed with vengeance for her sister, Nerina, who drowned herself after being seduced by Count Alfonso, the philandering illegitimate son of the King of Naples. Since Nerina's death, the enigmatic Violanta has lived chastely with her husband. She nevertheless enlists Simone as the assassin of Alfonso, who arives by gondola at the house on the Giudecca Canal, in the midst of Carnival celebrations. Alfonso's story of his upbringing and the sadness of his life totally undermines her resolve. A love duet is interrupted by Simone's expected arrival, and Violanta deliberately receives the fatal stabbing intended for Alfonso. 
We may take Violanta's beauty and mystery as a cliche of the time. She is a kind of Donna Anna figure, seeking revenge with a similar singlemindedness. In her persona she seems to be identified with Mona Lisa, and here the similarity with Schillings' heroine is uncanny. The Gioconda smile had featured in literary commentary since Byron. Swinburne, Pater and Wilde later developed the motif; Mario Praz suggested that Mona Lisa (like Swinburne's Faustine) is a vampire. The Goncourts had meditated on the subject in 1860 :

On croirait voir en elle une Violante, une de ces courtisanes du XVI siècle, un de ces êtres instinctifs et dérèglés qui portent comme ui masque d'enchantement, le sourire plein de nuit de la Joconde."

There is also a striking similarity with the plot of Smetana's Dalibor (1868): Dalibor is Milada's brother's murderer, but the girl falls in love with him nevertheless. What brings about the volte face is, of course, the wholly unexpected awakening of Violanta's sexuality. This event may' stretch the tolerance of some, but is just credible, even within the space of a one-act opera. The analogy with the with the dramaturgy of Salome is clear, as it is with Eine florentinische Tragödie, also heavily Salomeinfluenced. Violanta's emotional curve runs naturally from intense and justifiable hatred of a still unseen and threatening figure to the rapid arousal of passion, and willing self-sacrifice. Violanta's choking silence in Alfonso's presence is a remarkable coup de théatre, even if the work as a whole does not possess the tragic and coherent power of Strauss's Elektra.

Out of the opening idea, depicting Violanta's profound nature and inscrutability,

Fx 1

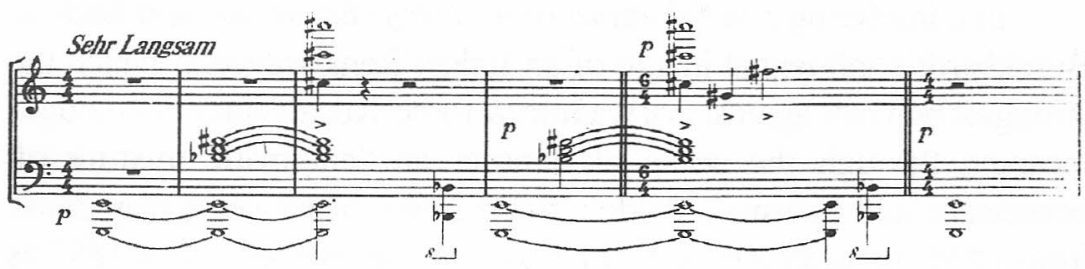


comes the whole work. It is not difficult to see in Alfonso's theme a rhythmic and harmonic resemblance to Jochanaan's motif in Salome. F.x 2

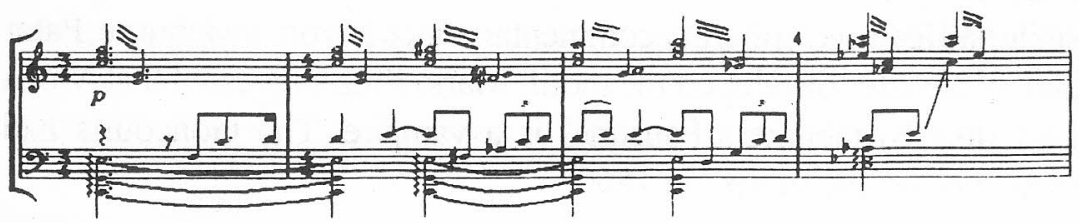

The Carnival background setting, including the "cheap song" "Aus den Gräbern selbst die Toten/Tanzen heute Brust an Brust ..." provides a sense of community in a work which derives its impact from the young Korngold's instinctive sense of orchestral colour and texture, his harmonic mastery - evident from the first bar - and his sense of sustained dramatictension. These were all duly acknowledged in Richard Stefan Hoffmann' searly biography. The Giudecca Canal house of Trovai is a superb symbol of wealth and splendour: the flamboyant artist Giovanni Bracca (a stock character perhaps) provides a foil for the main action, while the maid Barbara and her "old song" provides an echo of Emilia and Desdemona. Venice as a city of similar beauty and intrigue is presented herealmost for thelast time on theoperatic stage until Britten's Deathin Venice (1971-3) where it has become a place forever associated with Dionysiac abandon and fatal disease. In the year of Violanta's appearanceunder Bruno Walter's baton, another one-actopera, Venezia, by Erich Anders, was published in Berlin'28: this time showing two courtesans, the Provencal Heloise and Fiammetta, in love with the same French viscout, Emeste. He is eventually killed by the veiled Fiammetta out of jealousy. The setting is Fiammetta's palace in late 15 th century Venice and the stage is filled with celebrations - "ein toller Gewirr tänzender und lärmender Paare".

In considering Eine florentinische Tragödie we are sent back to Burckhardt's influential image of an Italian Renaissance in which the strongest bulwark against evil was moral force. Renaissance man sought meaning through the sense of honour, an "enigmatic mixture of conscience and egoism". Wilde's fragmentary blank-verse play dates from 1894, just after An Ideal Husband, and he referred to it in 1897 as 
his "Love and Death". It was one of a projected set of three plays on teh general theme of love. ${ }^{29}$ Charles Ricketts produced it in a double bill with Salome in London in 1906; years later in 1927, the Times critic commented on its "melancholy bejewelled rhetoric". There was a clear precedent in Wilde's completed verse tragedy The Duchess of Padua (1884) set in the late 16th century, which also has a Simone (Gerso), Duke ofParma, and a Guido (Ferranti) who loves the Duchess(Beatrice) and takes his own life at the end. The play was translated by Max Meyerfeld and published in Berlin in 1904. In another, unwritten dramatic project, a wife leaves her husband for her lover, denouncing selfsacrifice on the theory that love is the meaning of life. The husband challenges the lover to a duel, then kills himself. It was a matter of observation that Wilde, to engage his whole mind "felt a need for shadows". ${ }^{30}$

Whereas we can see Violanta as a virtuoso boy composer's tour de force, written without experience of life, Zemlinsky's one act Eine florentinische Tragödie cannot be judged in the same way. Hewas, after all, 44 when he composed the short score very quickly betweenthe spring of 1915 and 24 July, soon after finishing the magnificent and very personal Second String Quartet. Two years had passed since the Maeterlinck Songs op. 13 and five since the success of his Keller comic opera Kleider machen Leute. The Wilde fragment was first given in Max Meyerfeld's translation (Berlin, 1907) and Zemlinsky almost certainly saw it at the Vienna Burgtheater in 1909 (he was Music Director at the Volksoper until 1911). As a close friend of the Korngold family, he must also have been aware of Erich's progress on Violanta throughout 191415 , and may have been stimulated to attempt his own "Renaissance" tragedy. But in choosing this incomplete text, he was in fact, writing a work in code. The memories of his sister Mathilde's affair in 1908 with Richard Gerstl, the gifted young Viennese painter, her eventual return to Schoenberg and Gerstl's appalling suicide, were omnipresent to Zemlinsky, as his correspondence reveals. As Schoenberg had centred Die glïckliche Hand around two men and one woman, so Zemlinsky saw his chance to treat the same heated theme here. Debussy's Pelléas et Mélisande was given in Vienna in 1907, but this love triangle had been treated by Schoenberg in his 1905 symphonic poem, whose "fate" motif 
Zemlinsky consciously quoted:

Ex. 3
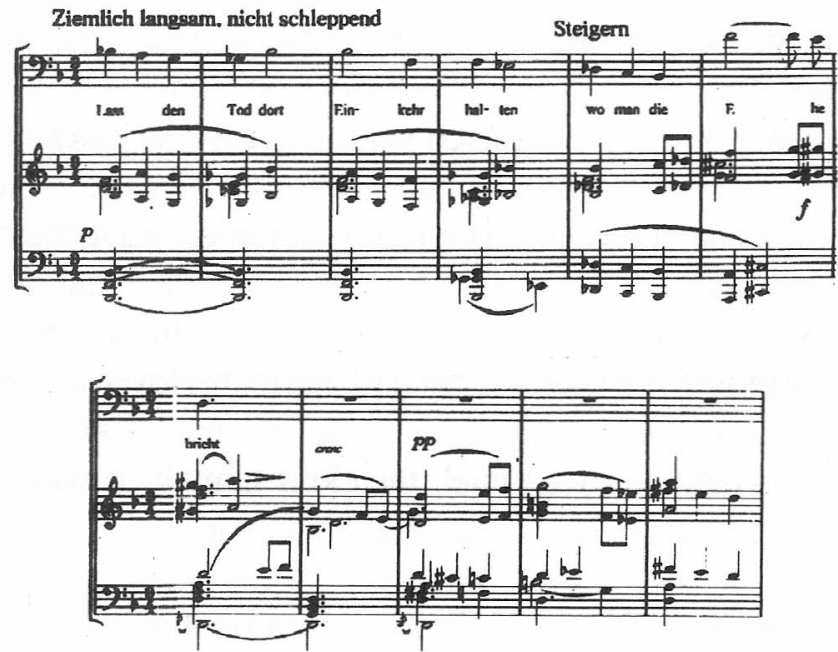

There was in Violanta, Eine florentinische Tragödie and Die Gezeichneten a tendency to embody the essential dramatic idea in a web oforchestral sound. Schreker's Vorspiel to Die Gezeichneten is the most extensive and remarkable of these, but the prelude to Eine florentinische Tragödie runs it close in quality. It was suggested from the start that Wilde's fragment needed dramatic amplification through presentation of the lovers' passion. Zemlinsky allegedly asked Meyerfeld to provide such a scene for him; Meyerfeld declined and Zemlinsky then wrotea Vorspiel in which (as in Der Rosenkavalier) the surging music says everything which words could not. It was also realised that the text was not a proper libretto; a real librettist would surely have made allowance at the close for the abrupt volte face of Bianca, more implausible altogether than that of Violanta. Zemlinskylater toyed with the idea of an orchestral interlude here to convey the transition, but nothing came of it.

The risk Zemlinsky took was simply that of setting Wilde's text as it stood, as a three-hander with one (baritone) part, that of the rich fabrics merchant Simone, dominating the other two. It emerges as an elaborate cat-and-mouse game, followed by a duel, then by a quite unexpected reconciliation. IfViolanta's central irony is the heroine's total about-turn, preceding a love duet of great beauty ("Reine Liebe") with the man she 
had planned to murder, then the main feature of Eine florentinische Tragödie is that of Simone deliberately concealing his perception of the true situation between Guido and Bianca until it suits him to reveal his true anger. The love duet between Guido and Bianca comes late in the action, as it does in Violanta, where it is also a prelude to violence. There are reminders of Tolstoy's obsessional story The Kreutzer Sonata (1889) although there Pozdnyshev kills his wife, not the lover Truchashevsky. "Beautiful things are made by those who strive to make something useful" said Wilde in $1884^{31}$ ten years before making his merchant Simonea man who deals in beautiful fabrics, and spends much of the time talking about them, about the cities he visits and about trade. He is a practical man; Guido, on the other hand, is just a rich philandering prince, whose main pride is in his blood and his heirdom to Florence.

The work has a certain relation to the plot of Monna Vanna (itself a distant echo of Measure for Measure) which appealed so strongly to German audiences of the time. There, the wife of the Pisan commander Guido Colonna, is faced with the sacrifice of her virtue to the Florentine general, for the salvation of the city. The general, Prinzivalle, tums out to have been a childhood friend of Monna Vanna and falls genuinely in love with her. Colonna disbelieves her denial that she has slept with Prinzivalle, but she leaves with Prinzivalle anyway. Shaw (among others) criticised the play for sentimentality and implausibility. The same might be said about the close of Eine florentinische Tragödie, where Bianca kneelsbeforeSimone. "Strenght" and "Beauty" arepervasive Jigendstil motifs, but their appearance in the form of a suddenly mutually admiring wife and husband over the corpse of the wife's lover, are rightly attacked as farfetched and even perverse. Yet a commentator in 1922 observed that this was a "strong man at last finding his way to the heart of a beautiful woman". ${ }^{32}$ Perhaps this is what drew Puccini to consider it briefly as a possible text for himself. A reviewer of 1924 generously said that it was a typical piece of Wildean "aesthetic-amorality". ${ }^{33}$ Musically, however, these curious lines provide a fitting conclusion (in the "love-key" of A flat) for a text which Adorno believed should have been consigned to the flames. 


\section{V - Schreker's Die Gezeichneten}

InDie Gezeichneten we are faced with Nietzschean-Burckhardtian image of the Italian Renaissance at its most beguiling. The "Durst nach Grosse', the love of enormities... condemned with vehemence but related with relish" as Peter Gay has put it, is present in the age of intrigue and voluptuary excess. It is very possible that Vitelozzo Tamare's name derives from Vitelozzo Vitelli in Gobineau's Cesare Borgia. One wonders, too, whether Carlotta was partly derived from Simonetta Cattanei, a Genoese-born beauty, painted by Botticelli, who went to Florence as Marco Vespucci's wife, dying of consumption aged 23. She may also have been in part an allusion to the celebrated, psychologically penetrative Venetian portraitist Rosalba Carriera (1675-1757). Also striking is the parallel with Schiller's early (1783) play about the 1547 Fiesko conspiracy, Die Verschwörnng des Fiesko zu Gemia. The date and place are the same, the philandering Fiesko di Lavagna is a "junger schlanker blühendschöner Mann von 23 Jahren - stolz mit Anstand freundlich mit Majestät - höfischgeschmeidig und ebenso tückisch (a young, slender man of 23 in the bloom of youth, of proud and noble bearing, friendly yet majestic, softly courteous yet malicious) remarkably like a politically ambitious and idealistic Tamare. Alviano's stabbing of Tamare recalls Fiesko's assassination by the much older Verrina at the end of Schiller's play. Fiesko features the historical Doge of Genoa, the aged Andrea Doria. In Die Gezeichneten, the "authority figure" is Herzog Adorno, the name of a leading Genoese noble family. Schiller's nobles are all dressed in conspiratorial black, but the young wife Leonore is "blass und schmächtig, fein und empfindsam" (pale and delicate, refined and sensitive).

J.J. Heinse's novel of 1787, Ardinghello und die glïckseligen Inseln has already been mentioned. Apart from the nearly contemporary Fiesko, this work also seems close to the ethos of Die Gezeichneten. The common factors are the work's location, Genoa as well as Venice, Rome and the Greek islands of Paros and Naxos, and the figure of Ardinghello himself(Prospero Frescolbaldi, a Florentine artist). As a type he has, like Schiller's Fiesko, features in common with Count Vitallozzo Tamare. Also present are murder, hopeless longing, seduction and the notion of 
an erotic Utopia borne up by the worship of Nature - Alviano Salvago's island Elysium, off the coast of Genoa. The text of Die Gezeichneten(The Fated Ones or The Stigmatised Ones-no translation is satisfactory) is by common consent his best. Even Theodor Adorno thought the opera his most successful, while Berg, always reluctant to praise Schreker, was much impressed by the composer's public reading of it in $1912 .{ }^{34}$ If the work also had 19th century ancestry (Stifter and Leopold Andrian) it had a recent successor in Manuel Mojica-Lainez' story of Pier Francesco Orsini, Duke of Bomarzo, like Alviano a cripple seeking beauty, in Ginastera's 1965 opera Bomarzo.

In approaching Schreker for a text on the theme of an ugly man's fate, Zemlinsky might well have anticipated the result - that Schreker himself would be seized by the idea, and wish to compose his own opera. Having already set to music Wilde's The Birthdoy of the Infanta for Grete Wiesenthal in 1908, the themes of exoticism, innocent beauty, pathos; passion, rejection and death or madness from heartbreak were much in his mund. The most striking and poignant resemblance is that between the dwarf's dreadful self-discovery in the Infanta's mirror, and Alviano's confession in the Atelier scene (Act2/2) that he had banned all mirrors from his palace.

What made Schreker choose Genoa as a setting, we can only guess. Genoa is along the Mediterranean coast from his birthplace in Monaco, but by the time Schreker had reached the age of awareness, the family moved to Linz. The island "Elysium" in which the crippled Count Alviano Salvago (so similar to Lorenzo dei Medici) creator an erotic paradise, is, of course, fictitious. No such island exists off the mainland. It is therefore a fantasy, in the way that the more hard-nosed brothel $L a$ Casa di Maschere in the Venetian lagoon in Der Ferne Klang is a fantasy. Elysium is more ambiguous, audacious and far-reaching, being a place of overwhelming beauty, created as such by the wealthy Alviano as a symbol of that which he so conspicuously lacked himself as a man-the generously given to the people of Genoa. The lengthy verbal introduction to Act 3 depicts a paradise garden, with grottoes, fantastic shapes, fountains, fauns, naiads, bacchantes and the distant Angelus bell. Yet from the start, Elysium, withits grottoes, statuary lights and underground passages, has been besmirched by the local nobility, and used, in effect, 
as a refuge for seduction and rape. The house of masks and the Maskenzug are not far apart: lewdness lies behind both. Elysium is a kind of corrupted Utopia, which mirrors the physical deformity of its creator. As a symbol, it also mirrors the connection of the private with the public domain, the union of a personal vision of beauty with the civic grandeur of a wider community. Vastly different in background and impulse, the composer Schreker would have understood the novelist E.M. Forster's injunction "Only connect" in Howards End. Theywere contemporaries and the text of Die Gezeichneten dates from the same year as the novel.

Alviano himself is a fiddle player and wears a cap and bells. He is beyond question a ghostly echo of Verdi's Rigoletto, especially at the end. Cinquecento Mantua has become cinquecento Genoa. Richard Hoffmann saw this in 1921, as he saw the Verdian links of the Irrelohe text with II Trovatore and the Memnon text with Aida. ${ }^{35}$ Alviano is as essentially unbalanced and depressive as Fritz (in Der ferne Klang) whose flight from Grete towards the "distant sound" is comparable with Alviano's dommed longing to believe that Carlotta genuinely loves him. Comparisons with the similarly dwarfish and misshapen Alberich in The Ring cannot be made. Alberich's destructive power and evil are at the opposite pole from Alviano's thirst for goodness and almost naive worship of beauty. Alviano has however been compared in type with Thomas Mann's later creation Helmut Institoris in Doktor Faustus (1943-6); a small, insignificant figure who, like the Swiss writer Conrad F. Meyer, is a lover of Nietzschean "Renaissance", living vicariously, worshipping strenght and power, or "strong and brutal instincts". Mann himself comments on the period dichotomy so clearly articulated in Die Gezeichneten and elsewhere. It was, he said, the opposition of "Ästhetik" and "Moral"

the conflict between a doctrinaire glorification of "life", in its splendid unthinkingness and the pessimistic reverence for suffering, with its depth and wisdom... ${ }^{36}$

Alviano says of Elysium that "the artists built it; I contributed only longing(Sehnsucht)". Carlotta, though startlingly beautiful, is physically frail-unlike the resilient Grete or the ruthless and determined Els in Der 
Schatzgräber. Tamare is aunidimensional Renaissance "Kraftmensch", a creature of physical appetite but crude sensibility, viewing himself always as an enemy of darkness, a searcher after light. He represents not only a Don Juan archetype, like the Duke of Mantua, but an aspect of heroic vitalism, a link with turn of the century ideas of the life force.

Recent comments by the pioneer German Schreker scholar Gosta Neuwirth have suggested that for Schreker historical accuracy in this opera was not really an issue, despite the detailed instructions for the Maskenzug in Act 3. Other commentators have sensed this, too. "Renaissance" here was an historical backcloth embracing essentially modern psychology and taking its place in part under the pressure of the censorship office in Vienna. Even the Bacchanalian procession takes its cue from Hans Makart's "Renaissance-classical" procession in Vienna in 1879, not to mention the great Ringstrasse celebration for the Emperor Franz Josef in 1908 on his 60th anniversary. Furthermore, Schreker seems to have drawn at least some of his characters from the real world, as he did in several other operas. Alviano is a combination of the dwarfish Zemlinsky and the hunchback Viennese poetess Edith Ronsperger, several of whose texts Schreker had set to music. ${ }^{37}$ Vitellozzo Tamare is in part drawn from the dissolute exhibitionist Archduke Otto (Franz Ferdinand's brother) who died of syphilis in 1906. He also happened to be an amateur artist, leading Schreker towards a vital aspect of the character of Carlotta. She in turn relates to the ailing singer Antonia in Offenbach's Tales of Hoffmamn; Antonia dies in thevery act of practising her art.

Carlotta is the daughter of the Podestà (Mayor) Lodovico Nardi, and therefore not of noble birth. But she is the embodiment of the educated Renaissance woman discussed by Burckhardt, while at the same time echoing the notion of the woman as painter and as weak, dependent vessel in Weininger's Geschlecht und Charakter (Gender and Char acter, 1903). Schreker's daughter called her an "intellectual, emancipated woman", whose true element and territory is beauty. ${ }^{38} \mathrm{An}$ artist of singular talent, who has studied at Antwerp, she contains something of Friedrich Schlegel's Greek womanly ideal, Diotima. She speaks warmly to Alviano, telling him that the artist's vocation is in the depiction of souls (as in Tolstoy): her painting of hands is a skill which 
she has developed to a level of morbid preoccupation. Before warning Tamare against pursuit of Carlotta, Duke Adorno acknowledgesher skill with the remark that "A great painter mentioned her name to me as someone of unusual gifts". But shealso hasa weak heart; for her, physical love means death, and indeed she collapses after her seduction by Tamare in one of Elysium grottoes, dying from shock following Tamare's own death by Alviano's enraged hand. This is a Liebestod of a particular kind. Carlotta's love for Alviano is a phantom one, born of the artistic impulse alone, and exhausted when her portrait of him is complete. This Jugendstil heroine is as trapped in her own circumstances as Melisande. But she is bolder and angrier, excoriating herself with self-abasing guilt after the evaporation of her feeling for the crippled man.

Carlotta's feeling for Tamare isvery slow to develop, but overwhelms her once she has given herself to him. Tamare boasts to Alviano that Carlotta was his from their first meeting (untrue, as it happens)- echoing PaoloCalvi's wordsin Act I that "Die SchönheitseiBeutedes Starken" (Beauty must be the prey of the strong). The richly chromatic language of Die Gezeichneten expresses a closeted warmth, a hazy intoxication, the lingering tension of annihilating sweetness. This $\mathrm{D}$ major passage from the Vorspiel recurs near the end of the scene in Carlotta's studio (Act 2 Scene 2), this time in A major, at the point of closest contact and understanding between Carlotta and Alviano.

Ex. 4
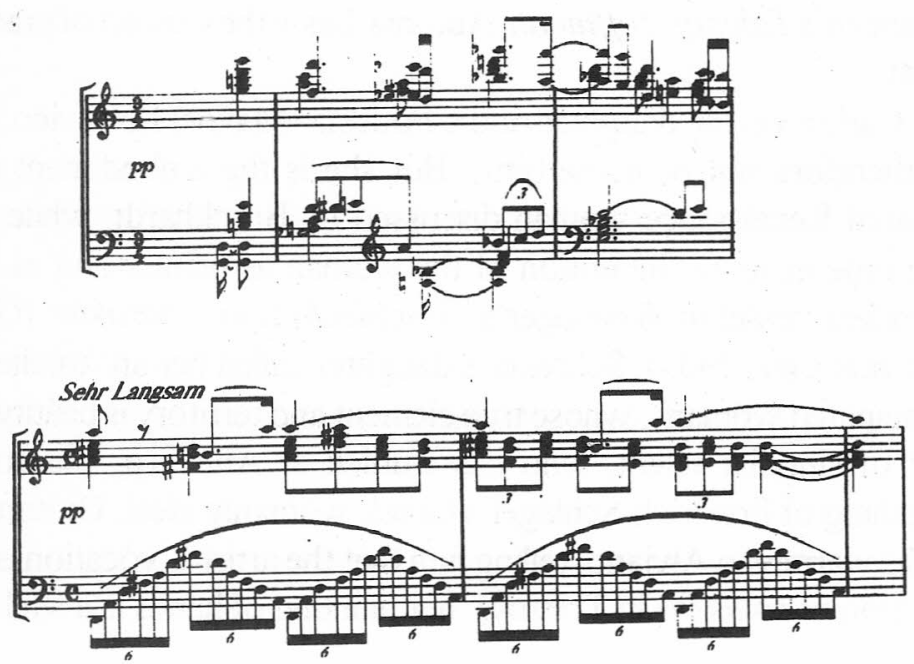
As in Tristan un Isolda but more perversely, Tamare's death means Carlotta's death too. Yet there is no redemption or union in death here. Catherine Clément would argue that she was doomed anyway, like virtually all operatica heroines. ${ }^{39}$ Carlotta lacks the straight pathos of Mimi or Butterfly, and is without the Marschallin's poise and dignity. Here, as throughout Schreker's operas, "Mann" and "Weib" are polar opposites, or "partnersinabisexual universe". ${ }^{40}$ We know that Schoenberg and Berg were avid readers of Karl Kraus Die Fackel during the years of its greatest success. So all-pervasive was its influence in Viennese artistic and intellectual circles that it is hard to imagine Schreker avoiding it. Kraus developed a public image of female sexuality which sprang from a notion of female "Hirnlosigkeit" (brainlessness) the cult of the promiscuous low-class hetaera in contemporary Vienna. This was as (Edward Timms has shown) at variance with his main real-life friendships with women, though it does fit the sad figure os Irma Karczewska. ${ }^{41}$ In 1909 Kraus declared that the sensuality of woman "is the primal spring (Urquell) from which the intellectuality (Geistigkeit) of man finds renewal". This is strikingly close to the Schrekerian world. In 1907 Kraus climbed Mount Vesuvius, directly relating in Die Fackel the image of sexuality as a volcanic eruption, "relating metaphorically to the collapse of civilisation". +2

Die Gezeichneten was a Jugendstil fantasy employing many specific images of the Italian Renaissance as background colour for a tragedy of thwarted desireand failed self-realisation, all too contemporary in flavour. In his detailed and sensitive Thematic Analysis of Die Gezeichneten published in 1922, Schreker's pupil Walter Gmeindl mentions the specific Renaissance Genoese setting only once, calling the work a tragic tale of misused beauty. ${ }^{43}$ With modern psychology and the presence of large crowds on the stage, this work also declares its allegiance to the pioneering cinematic creations of D.W. Griffiths. Schreker was not fastidious enough with words to give his characters fully-rounded verbal credibility and his many small solecisms led to early criticism, like that of Robert Prechtl in his well-known article Opern Tod (The Death of Operas: open letter to Franz Schreker). ${ }^{4}$ The questions one eventually asks about Die Gezeichneten are rooted in our interest in 
character-portrayal and behaviour through musical expression, rather then in the "authentic" re-creation of a Renaissance Mediterranean setting. The work's warm reception in 1918-21 (including a Vienna production, denied to Der ferne Klang until 1991) helped to confirm Schreker's reputation, though productions fell away after Bekker's in 1927. It was an early candidate for concert performance in the 1950 s and 1960s, initially through broadcasts, well before the Zemlinsky and Korngold revivals.

One does not need to go far in the historiography of the high Renaissance, in particular the Italian Cinquecento, to see references to the "joyous longing for human autonomy" to "pride in the supremacy ... of theintelligence", to "productiveoptimism" and "an unrestrained, heroic concept of life". ${ }^{45}$ As literary Renaissanceism declined sharply with the First World War, so these three operas, all stemming from the Viennese ethos, and drawing on the Viennese attitude to Italy and its seaboard, represented a rich, final echo of a dying theatrical tradition. They also represented a craving for something lost, rather than an attempt to look forward. In each one we can feel a sharp sense of place, a preoccupation with luxury, sensuality and voluptuousness, as opposite poles to fear, decay, anarchy, immoralism and oppressiveness. The "last gasp" of Wildean- Jugendstil aestheticism, produced by two VienneseJewish composers is found in Korngold's Venice and Zemlinsky's Florence, creating images of beauty which were also images of painful nostalgia and darkness. Weare reminded that Mann, speaking of his own play Fiorenza, said that he intended the Italian Renaissance to be criticised, not glorified. ${ }^{46}$ Fiorenza preferred asceticism to sensuality, as Pfitzner's Palestrina exalted the individual creative spirit against the brutish world. Pfitzner's musical language, richly embedded in postWagnerian chromaticism, also sought the archaic and (it has been said many times) the ascetic, or esoteric, as a means of giving the sixteenth century a greater theatrical immediacy. ${ }^{47}$ Schreker tried to do this for Renaissance Genoa in Die Gezeichneten by quite opposite means, using opulent harmonies and elaborateinstrumentation to represent the dream, yearning and inner torment contained in the action. We can fairly say that in this work, as elsewhere, Franz Schreker inherited a conception of the creative artist from the early German Romantic period (Wackenroder 
and Hoffmann) and developed it in line with his own time - the age of Wilde, Nietzsche, Weininger and Frank Wedekind. The artist as "exemplary man" of genius, promulgated by Karl Kraus ${ }^{48}$ and the woman as sufferer and victim lie at the heart of all his work.

\section{Summary Chronology}

\begin{tabular}{|c|c|}
\hline 1906 - & Hauptmann's Und Pippa tanzt! \\
\hline $1907-$ & $\begin{array}{l}\text { Max Meyerfeld's translation of Wilde's A Florentine Tragedy } \\
\text { (1894). }\end{array}$ \\
\hline $1910-$ & Schreker writes the libretto of Die Gezeichneten. \\
\hline & $\begin{array}{l}\text { Pfitzner wirtes the libretto of Palestrina (composition begun } 1 \text { Jan. } \\
\text { 1912). }\end{array}$ \\
\hline $1911-$ & Ernst von Dombrowsky's play Mona Lisa given at Graz. \\
\hline $1912 / 13-$ & $\begin{array}{l}\text { Beatrice Dovsky's libretto for Mona Lisa written and sent to } \\
\text { Schillings. }\end{array}$ \\
\hline $1912 / 13=$ & Henri Février’s opera after Maeterlinck Monna Vanna. \\
\hline 1912 (18 Aug) - & Schreker's Der ferne Klang 1st performance, Frankfurt. \\
\hline $1913-14-$ & $\begin{array}{l}\text { Composition of Schillings' Mona Lisa (text published by UE } \\
\text { 1914). }\end{array}$ \\
\hline $1913-15-$ & Schreker composes Die Gezeichneten. \\
\hline $1914-$ & Hans Müller offers E.W. Korngold text of Violanta. \\
\hline 1914-15 (summer) & E.W. Korngold (aged 16/17) composes Violanta. \\
\hline $1914(26 \mathrm{Dec})$ & Busoni completes libretto draft of Doktor Faust. \\
\hline $1914-16-$ & Busoni composes Arlecchino: a theatrical capriccio in 1 Act. \\
\hline 1915 (24 Jun) & Pfitzner completes composition on Palestrina. \\
\hline 1915 & \\
\hline (Spring-24 July) & $\begin{array}{l}\text { Zemlinsky composes short score of Eine florentinisch } \\
\text { Tragödie. }\end{array}$ \\
\hline 1915 (26 Sept) & Première of Mona Lisa, Sttutgart. \\
\hline $1916-$ & Erich Anders' Venezia (1 act) published Berlin by Carl Jatho. \\
\hline (28 Mar) & Violanta premièred in Munich (cond Walter). \\
\hline (10 Apr) & Violanta premièred in Vienna, with Jeritza in title role. \\
\hline (2 June) & Zemlinskycompletes orchestration of Eine floretinische Tragödie \\
\hline$(4 \mathrm{Oct})$ & $\begin{array}{l}\text { Strauss's Ariadne auf Naxos, second version, premièred in } \\
\text { Vienna with Lotte Lehmann as the Composer. }\end{array}$ \\
\hline $1917(30 \mathrm{~J}$ & Première of Eine floretinische Tragödie, Sttutgart, cond. Schillings. \\
\hline (11 May) & Première od Arlecchino, Zurich. \\
\hline
\end{tabular}


(12 Jun)

1918 (25 Apr)

(Autumn)
Première of Palestrina, Munich, cond. Bruno Walter. Première ofDie Gezeichneten, Frankfurt, cond.LudwigRottenberg. Full text of Busoni's Doktor Faust published in Die Weissen Blätter, Berlin.

\section{References}

1. Quartet in Barbara Tuchman: The Proud Tower : a portrait of the world before the war, 1890-1914. Macmillan 1966, p. 301.

2. Ernst Krause: Richard Strauss: The Man and his work. Collet, London 1964, p. 299.

3. Paul Bekker: Elektra: Studie (Neue Musik Zeitung 14, 16, 18 of 1909). Tr. Susan Gillespie in Bryan Gilliam (ed) Richard Strauus and his World. Princeton UP 1922, pp. 372-405.

4. Michael Kennedyin Strauss (J.M. Dent, London 1974), pp. 157-8 and in a 1993 $\mathrm{BBC}$ broadcast, referring to the 1916 version.

5. Franz Schreker 1878-1934: a cultural biography. Cambridge UP 1993.

6. Edward Timms and David Kelley (eds) Unreal City: Urban Experience in Modern European Literature and Art. Manchester UP 1985, ch. 15.

7. Vienna and the Jews 1867-1938: a cultural history. Cambridge UP 1988.

8. The text of Die glückliche Hand first appeared in Der Merker 1911. Repr. in Jelena Hahl-Koch tr \& ed Arnold Schoenberg/Wassily Kandinsky: Letters, Pictures, Dociments. Faber 1984, pp. 91-98.

9. Pfitzner had conceived the Palestrina idea as early as 1895 , when he was only 26. Busoni's Doktor Faust also dates back to the 1890s in conception. A previous Palestrina opera, in five acts, byM.E. Sachs, was given at Regensburg in 1866.

10. The Music of Hans Pfitzner. Oxford UP 1992, p. 148.

11. Hans Pfitzner in Music and Letters 1923, p. 127. Walter's comment quoted by Erwin Kroll in Hans Pfitzner, Drei Masken Verlag, Munich 1924, pp. 47-8. Pfitzner's main sources were A.W. Ambros' Geschichte der Musik(1878) and the histories of the Council of Trent by Sarpi and Pallavicini.

12. Tr. Anthony Beaumont in Busoni the Composer, Faber 1985. Beaumont has also set out, for the first time, the full chronology of Doktor Faust's composition, from September 1916 to May 1923. Ibid. pp. 325-327.

13. Reflections of a non-politicalman. Tr. WalterD. Morris, Frederick Ungar. New York 1983, p. 300f.

14. See Jon Newsom: Hans Pfitzner, Thomas Mann and The Magic Mountain. Music \& Letters 1974, pp. 139-50.

15. Rudolf Felber: Hans Pfitzner. Musical Quarterly 1924, p. 137. 
16. Paul Bekker Gesammelte Schriften. Deutsche Verlags Anstalt, Berlin 1992 , Vol. 2, p. 275: Mann Reflections, p. 311.

17. Arthur Eloesser: Deutsche Literatur von der Romantik bis zur Gegenwart. Cassirer, Berlin, 1931, p. 519.

18. Published in Pan 5, pp. 199-203.

19. First given at the Vienna Burgtheater in 1902, as a vehicle for Eleonore Duse, and presented in Berlin only nine days later. Published in Neue Rundschau 13 (1902), Heft 10, pp. 1040-80; book version Jena 1902.23.000 copies were sold by 1920 .

20. Richard Specht:ArthurSchnitzler: Der Dichter undsein Werk. Fischer, Berlin, 1922, p. 184.

21. Hugo von Hofmannsthal: Gesammelte Werke: Gedichte und Lynische Dramen, p. 139.

22. Hermann Broch: Hugo von Hofmannsthal and his Time. The European Imagination 1860-1920 (tr. \& ed. Michael Steinberg). Chicago UP, 1984, p. 130.

23. Hermann Bahr: Die Décadence, quoted in Ruprecht and Bänsch (eds.) Literarische Manifeste der Jahrhundertwende. Stuttgart, 1970, p. 305.

24. Robert Musil: The Man witout Qualities. Tr. Wilkins \& Kaiser, Secker and Warburg. London 1955, Vol. 1, p. 92.

25. Strauss-Hafmannsthal Correspondence. Trad.\& ed. Hammelmann and Rose, Collins, 1961. p.3.

26. Unpublished Memoirs of Julius Korngold, p. 184.

27. Mario Praz: The Romantic Agony. Oxford UP, 1935, p. 313.

28. C.J. Jatho, Berlin, 1916.

29. Richard Ellmann: Oscar Wilde. Hamish Hamilton, 1987, p. 388.

30. Ibid., p. 247.

31. Lecture The Value of Art in Modern Life, qu Ellmann, p. 247.

32. Philipp Aronstein: Oscar Wilde: sein Leben und Lebenswerk. Deutsche Bibliothek in Berlin, 1922, p. 106.

33. (Walter) Kemp in Musikblätter des Anbruch, 1924. Reviewing the Aachen production.

34. Quasi una fantasia: Essays on Modern Music. Tr. Rodney Livingstone. Verso, 1992, p. 140. [orig. Suhrkamp, Frankfurt, 1959]

The Berg-Schoenberg Correspondence (tr. and ed. Brand, Hailey and Harris). Macmillan 1987, p. 89n. (letter of 1 or 8 May 1912).

35. R. St. Hoffmann: Franz Schreker. E.P. Tal \& Co, Leipzig \& Vienna, 1921, p. 161.

36. Thomas Mann, tr. H.T. Lowe-Porter, Doktor Faustus. Secker and Warburg 1949, p. 287.

37. Jürg Stenzl (ed.) Art Nouveau, Jugendstil und Musik. Atlantis Verlag, Zürich, 1980 , p. $113 f$. 
38. Haidy Schreker-Bures Hören, denken, fühlen. Eigenverlag, n.d., p. 339, 41.

39. Opera or the Undoing of Women. Tr. Betsy Wing. Virago Press, 1989.

40. Die Fackel 389/90, quoted in Edward Timms, Karl Kraus: Apocalyptic Satirist, Yale UP, 1986, p. 92.

41. E. Timms and R. Robertson(eds.) Vienna 1900: from Altenberg to Wittgesntein. Edinburgh UP, 1990, p. 87ff.

42. Sprüche und Widersprüche, 1909, qu. Timms, Karl Kraus, p. 83.

43. Walter Gmeindl: Die Gezeichneten: Thematische Analyse. Universal Edition, 1922.

44. Robert Prechtl Opern-Tod: Offener Brief an Franz Schreker. Melos II (1921), pp. 51-56.

45. From Luigi Firpo: Political Philosophy: Renaissance Utopianism (1957) in Eric Cochrane (ed.) The Late Italian Renaissance 1525-1630. Macmillan, 1970, p. 153.

46. Ilsedore B. Jonas, tr. Betty Crouse, Thomas Mann and Italy. Alabama UP, 1979, pp. 33-34.

47. John Williamson: The Music of Hans Pfitzner. Oxford UP, 1922, p. 204.

48. Qu Edward Timms Karl Kraus, p. 198.

Robert Blackburn, assistant dean. Faculty art \& musica Bath Collegue of Higher Education. England. 